\title{
REVIEW OF SUSTAINABILITY OF AVERAGE NEPALESE SUBSISTENCE FARM IN MID-HILLS OF NEPAL
}

\author{
Tilak R.Chaulagai ${ }^{1}$
}

\begin{abstract}
The main aim of this paper is to depict the sustainability condition of an average subsistence farm in the mid-hill condition of Nepal. For the purpose, a hypothetical farm representing the average condition of the farming system in the area is taken. The analysis is based on the secondary information. For the purpose, only few indicators for the sustainability are analysed including gross profit margin, nitrogen use efficiency and nitrogen balance. The results reflect that an average subsistence farm in the midhill of Nepal earn just NRs 79,449 per annum. The nitrogen balance was negative and nitrogen use efficiency was more than $100 \%$ reflecting the system was economically and environmentally unsustainable. The problem behind unsustainability of the system is basically related with poverty and increased population pressure on poorly fertile land. Only a joint venture of public and private sector can address the problem.
\end{abstract}

Key words: Ecological, Economic, Poverty, Social, Sustainability

\section{INTRODUCTION}

Sustainability is a contextual concept and it's definition depends on the dimensions on which we want to focus on. If we want to focus on the environmental concerns of any production process or system, we will be looking for the environmental sustainability. If we want to know how much the proposed production process is profitable, efficient and productive, then we look for the analysis of economic sustainability. If we want to know the societal concerns and benefits to the society we have to analyse socio-cultural sustainability. It is a subjective concept and the meaning is given from different perspectives (Boogaard et.al., 2008). Thus, an agricultural sustainability analysis comprises the study of all three components of sustainability namely social, ecological and economical (OECD, 2008). Further, as mentioned by Kates et.al., (2005) Brundtland Commission defines sustainability as "ability to make the development sustainable - to ensure that it meets the needs of the present without compromising the needs of future generations to meet their own needs" which is the most widely used and accepted definition of sustainable development.

The developing countries' economy is mainly based on agriculture. Agriculture in those countries is of subsistence nature. Majority of the people are based on agriculture for their livelihood. The farming system of those countries is characterised by small holding or low access to land, little or no capital for investment in improved technology, hardly any off farm employment opportunities and complex and diverse in fragile environment (Altieri, 2002). Resource poor farmers do not benefit from the modern technologies because these technologies are not affordable and/or inappropriate for their conditions.

\footnotetext{
1 Ministry of Agricultural Development, Singh Durbar, Kathmandu, Mobile : 9843664402, Email: tilak034@gmail.com
} 
Nepal is not an exception and facing the similar problems mentioned above. Geographically, Nepal is divided into three regions namely; High Hills, Mid Hills and Terai. High hills and mid hills have difficult topography and sloping land of different degrees. Out of 54 lakhs 27 thousand Nepalese households, 38 lakhs 31 thousand (around $70.59 \%$ ) are involved in agriculture and 83 percent of the total farm households' major income source is agriculture (CBS, 2011/12). Moreover, the sector contributes 34.38 percent to national gross domestic production (MoAD, $2012 / 13)$. These figures imply that agriculture is an important sector regarding its contribution to the national income and employment. CBS $(2011 / 12)$ has estimated that 25 lakhs 25 thousand hectares land in the country was being used for crop cultivation. The average holding of agricultural land by the Nepalese farming household has been decreasing over time. For instance, the average size of holding was 0.8 hectares per household in 2001 that had decreased to 0.68 hectares in 2011 (CBS, 2011/12). Moreover, CBS (2011/12) further mentioned that the total number of parcels has increased from 1 crore 10 lakhs in 2001 to 1 crore 20 lakhs in 2011 implying that the land fragmentation has also been increasing over time. The decrease in the size of holding is due to land fragmentation and this is further conditioned by the division of the parents' land to their sons. This shows that Nepalese farmers are small subsistence farmers with scattered parcels of land of very small size.

The farming system in mid-hills of Nepal is characterised with small holding, subsistence, mixed with few animals and crops and basically cereal based. The farmers do not grow their crops for selling in the market. Generally, they do not grow vegetables and if they do so, they grow in a very small scale only for the home consumption. The major crop rotations in mid-hills of Nepal are rice-wheat on khet (local name for irrigated land), millet either relayed or grown sequentially after maize on rain-fed bari (local name for unirrigated land) and rice-blackgram on ancient river terraces, tar land (Pilbeam et.al., 1999). They further mentioned that bari land receives more manure than khet and khet receives greater proportion of little chemical fertilizers. It indicates that the use of chemical fertilizers and manure in both of these lands are low resulting in the depletion of soil nutrient rendering the land more and more non-fertile.

Also, increased population pressure on the limited land in the country has resulted nutrient deficiencies in the soil. Whatever the nutrients uptake by the plants in the form of biomass should be replaced with either chemical or organic sources to maintain the soil fertility. The lack of proper nutrient management practices in developing countries has led to ever decreasing nutrient balance in the production place. Goulding (2007) mentioned that intra and intercontinental transfer of nutrients in the form of products has resulted in the degradation of land in some countries and surplus of nutrients and environmental pollution in other countries. For instance, he further noted that the import of nutrients into the Sub-Saharan African countries went to the cities, leaving a waste disposal problem that were not used to manage nutrient losses to the farm land.

Small holdings, fragmented land, cereal based subsistence mixed farming system with increasing pressure on land due increased population pressure are really challenging to the sustainability of the system. It is interesting to analyse the 
system to know whether the system is economically, ecologically and socially sustainable or not. In this regard, the aim of this report is to present the status of different sustainability aspects of the system and to propose some probable solutions.

Based on the aforementioned propositions and facts, the central question to be addressed with this paper is postulated as:

"Whether the system is economically viable, environmentally feasible and socioculturally acceptable or not?"

This study uses literature based secondary information. The system was more complicated having different types of lands, crops and livestock in the same time. All the calculations based on limited information from the literature are not sufficient to generalize the outcomes of the study. Findings of this report provide a general picture of sustainability status of such types of farming systems. As the calculations are based on only one farm, the finding cannot be verified statistically and cannot be generalised.

This paper is presented in different chapters. Chapter two describes the methods that are used to calculated and/or analyse the sustainability indicators. Chapter three presents the results based on the analysis. At the end of this paper conclusion is made based on the discussion and result of the study.

\section{MATERIALS AND METHODS}

The analysis was based on the secondary information/data and calculations were performed manually. The following indicators were selected for measuring sustainability.

Economic sustainability: Gross Profit Margin

Ecological sustainability: Nitrogen balance and Nitrogen Use Efficiency

Socio-cultural sustainability: Self-sufficiency for the Farm Family

For the purpose, single farm is assumed with the following characteristics:

Table 1. Assumed Characteristics of the Study Farm

\begin{tabular}{ll}
\hline Parameters & Size \\
\hline Family size (CBS, 2011: average family size in Nepal is 4.7) (number) & 5 \\
Total cultivated area (ha.) & 1 \\
Area under bari (unirrigated land) (ha.) & 0.5 \\
Area under khet land (irrigated land) (ha.) & 0.5 \\
Kharbari (slopy land for natural grass- not planted) (ha.) & 1 \\
Number of animals & 1 \\
$\quad$ Buffalo & 2 \\
Cow & 3 \\
$\quad$ Goat & \\
\hline
\end{tabular}


The author had also assumed that in bari land the farmers used maize-finger millet based and in khet land they used rice-wheat based cropping system. They did not use chemical fertilizers for finger millet but used for rice, wheat and maize cultivation but in small amount. They fed the buffalo with only 1 kilogram $(\mathrm{kg})$ of concentrates (maize flour) produced in his/her own farm and that for cow and goat was $0.5 \mathrm{~kg}$ and $0.2 \mathrm{~kg}$ respectively per animal per day. Besides, the farmer cut the grass from his/her own farm to feed animals in shed. The goats were taken to the Kharbari for grazing. This assumption was based on the study from Pilbeam et al. (1999) who stated that in most part of the mid-hills of Nepal, farming families have two types of land; rainfed bari land dominated with the maize based cropping system and irrigated low land (khet) dominated with the rice-wheat system.

The result was presented based on the mathematical calculations. For calculating the net profit margin from livestock, secondary information consistent with this situation was used. Net profit margins from crop lands were calculated as the difference between total return and total cost. The nitrogen use balance was calculated as the difference between total nitrogen inflow into the system and outflow from the system. The inflow is in the form of fertilizer and atmospheric deposition. The outflow is in the form of plant and animal products. Nitrogen use efficiency was calculated as the ratio of inflow and outflow of nitrogen into and out of the system respectively. The study lacks using inferential statistical analysis. Only an average farm having some characteristics as illustrated in table 1 was assumed for just calculating the single parameter of three sustainable dimensions.

\section{RESULTS}

\section{ECONOMIC SUSTAINABILITY: GROSS PROFIT MARGIN}

Pilbeamet.al., (1999) conducted field research on midhill condition of Nepal and concluded that grain and straw yields of maize, upland rice, wheat and rice were greater at the higher rate of Nitrogen and for most of the crops labour cost exceeded the market value of the yields from zero input treatments. They found that application of only manure, fertilizer plus manure in low dose had resulted in negative gross margin and only high fertilizer application and mix of high fertilizer and manure treatment had given positive gross margin in the upland condition and in some of the low land condition also.

Khan and Usmani (2005) conducted a study in small holder farming community in hilly areas of Pakistan and reported that the average productivity of buffalo was 7.9 litres milk/day or 2370 litres milk per lactation and that of local breed of cow was merely 2.5 litres per day. They also reported that, in small holder farming, the livestock farming mainly dependent on self-growing local grasses for grazing and only milk animals are fed with concentrates. After analysing the benefit cost of livestock production, they reported that average gross profit were Rs. 32475 per buffalo, Rs 3320 per sheep and Rs. 5314 per goat per year but the gross margin per cow was negative and the farmers were sustaining a loss of Rs. 1960 per year. (Note : 50 Pakistani rupees $=46$ Nepalese rupee).

Based on the study of Khan and Usmani (2005) the author presented the economic calculations of livestock part of the farm in table 2. 
Table 2. Gross Profit Margin from Livestock Sector of the Farm

\begin{tabular}{ccccc}
\hline Animals & $\begin{array}{c}\text { Number } \\
\text { of }\end{array}$ & $\begin{array}{c}\text { Gross profit } \\
\text { margin (per }\end{array}$ & $\begin{array}{c}\text { Gross profit margin per } \\
\text { animal in 2010 price (NRs) }\end{array}$ & $\begin{array}{c}\text { Total gross profit margin } \\
\text { per vear (NRs) }\end{array}$ \\
\hline Buffalo & 1 & 29877 & 46414 & 46414 \\
Cow & 2 & -1803 & -2800 & -5600 \\
Goat & 3 & 4890 & 7600 & 22800 \\
Total & & & & 63614 \\
\hline
\end{tabular}

Source: adapted from Khan and Usmani (2005)

Note : Gross profit margin for the year 2010 is calculated from the Nepalese commodity price index (155.35 compared with 100 in 2005) retrieved Dec 7, 2011 from : http://www.indexmundi.com/facts/nepal/consumer-price-index. NRs is the Nepalese currency.

Table 3 shows that the farm is earning only NRs 79449 per year. It is very low for fulfilling the off-farm demands of the family. Even the gross profit margin from cow and finger millet were negative. The total gross profit margin from the bari land were negative. So, they are cultivating the land and growing the animals as a last resort. It sounds that the system is not economically viable. Animal farming specially buffalo and goat seems to be more profitable. Overall, the system has been earning NRs 79449 per year. This amount is not sufficient to make even an ordinary living for a family with five members.

Table 3. Gross Profit Margin from the Crop Sector and Whole Farm

\begin{tabular}{|c|c|c|c|c|c|}
\hline \multicolumn{6}{|c|}{ Bari } \\
\hline Crop & Area & Production $(\mathrm{kg})$ & Cost (NRs.) & Total return & Gross profit margin \\
\hline Maize & 0.5 & 1557 & 10513.5 & 17739 & 7225.5 \\
\hline Millet & 0.5 & 560 & 25400 & 16800 & -8600 \\
\hline \multicolumn{5}{|c|}{ a. Total from bari } & -1374.5 \\
\hline \multicolumn{6}{|c|}{ Khet } \\
\hline Crop & Area & Production $(\mathrm{kg})$ & Cost (NRs.) & Total return & Gross profit margin \\
\hline Rice & 0.5 & 1739 & 12841.5 & 22874.5 & 10033 \\
\hline Wheat & 0.5 & 1489 & 12530.5 & 19707 & 7176.5 \\
\hline \multicolumn{4}{|c|}{ b. Total from khet } & & 17209.5 \\
\hline \multicolumn{5}{|c|}{ c. Total Gross Profit Margin from the crops $(a+b)$} & 15835 \\
\hline \multicolumn{5}{|c|}{ d. Total Gross margin from the animals (from table 2) } & 63614 \\
\hline \multicolumn{5}{|c|}{ e. Total gross margin from the system $(c+d)$} & 79449 \\
\hline
\end{tabular}

Source: Adapted from MOAC (2010), and DOA (2009/10)

\section{ECOLOGICAL SUSTAINABILITY: NITROGEN USE EFFICIENCY (NUE)}

Agri food Consulting International (2003) reported that in Hilly area of Nepal, 68.2 percent of households use fertilizers in cereals, 37.4 percent use fertilizer in cash crops and 24.7 percent of them use fertilizer in vegetables with overall 80.7 percent of the households in the region use fertilizers to the crops. They have also reported that, on an average, for cereals $4592 \mathrm{~kg}$, for cash crops 3,607 kg, for 
pulses $2247 \mathrm{~kg}$, for vegetables $6898 \mathrm{~kg}$ manure and for overall $24 \mathrm{~kg} \mathrm{~N}, 12 \mathrm{~kg} \mathrm{P}$ and $24 \mathrm{~kg} \mathrm{~K}$ had been used per hectare of crop land per year.

With this reference and based on his experience on the similar farming community, the author has assumed that $\mathrm{N}$ use for rice, maize and wheat were $14 \mathrm{~kg}$ for half hectares each and for finger millet, no chemical fertilizers was used. Certain assumptions are made by the author to calculate NUE. The concentrates were produced on farm. The study assumed that the farmer did not have to import any inputs except fertilizers. The calculation of Nitrogen Use Efficiency of the farm is presented in table 4 where the input and output of $\mathrm{N}$ is expressed in $\mathrm{kg} / \mathrm{year}$ for the system. The outflow of nitrogen from the system was calculated as follows:

- $\quad$ For outgoing $\mathrm{N}$ in rice and wheat grain yield = Yield (in $\mathrm{kg}){ }^{*} \mathrm{~N}$ content $/ \mathrm{kg}$

- $\quad$ For outgoing $\mathrm{N}$ as maize and millet grain yield = Yield (kg) * Grain protein (proportion) * proportion of $\mathrm{N}$ in protein

- $\quad$ Cow milk $\mathrm{N}=$ Number of cow * milk yield $(\mathrm{kg}) /$ day * lactation period (days)*Milk protein content (proportion) * Protein N content (proportion)

- $\quad$ Buffalo milk $\mathrm{N}$ = milk yield $(\mathrm{kg}) /$ year * Milk protein content (proportion) * Protein $\mathrm{N}$ content (proportion)

- Goat meat $N$ = Number of goat * average weight of goat at sale $(\mathrm{kg})$ * meat protein content (proportion) * Protein $\mathrm{N}$ content (proportion)

Table 4. Nitrogen Use Efficiency and Nitrogen Balance in the System

\begin{tabular}{cllll}
\hline \multicolumn{2}{c}{ Inputs N (kg/ha/year) } & \multicolumn{3}{l}{ Outputs (kg/ha/year) } \\
\hline Fertilizer nitrogen (kg) & Amount N & Plant products & Description & Amount N (kg) \\
Rice & 14 & Rice grain & $1739^{*} 0.0113$ & 19.65 \\
Wheat & 14 & Wheat grain & $1489^{*} 0.0204$ & 30.37 \\
Maize & 14 & Maize grain & $(1557-730)^{*} 0.112^{*} 0.168$ & 15.56 \\
Atmospheric Deposition N & 50 & Millet grain & $560^{*} 0.072^{*} 0.168$ & 6.77 \\
\hline & & Animal products & & \\
& & Cow milk & $2 * 2.5^{*} 255^{*} 0.0654^{*} 0.168$ & 14 \\
& & Buffalo milk & $2370^{*} 0.0654^{*} 0.0168$ & 26.04 \\
& & Goat meat & $3^{*} 25^{*} 0.19^{*} 0.168$ & 2.39 \\
\hline Total Input & 92 & Total output & 114.77 \\
N balance in the system & & $92-114.77=-22.77$ & \\
Nitrogen use efficiency & & $114.77 / 92=125 \%$ & \\
\hline
\end{tabular}

Source : Generated based on the above mentioned assumptions and the sources mentioned in the succeeding paragraph.

The nitrogen content in rice grain is $1.13 \%$ (source: http://www.fao.org/docrep/t0567e/T0567E08.htm) and that of wheat grain is 2.04\% (Source: http://en.wikipedia.org/wiki/Eleusine_coracana) and protein content for maize is $11.2 \%$ (source: http://www.fao.org/docrep/t0567e/T0567E08.htm) and protein content in finger millet grain is $7.2 \%$ (Source: http://ltras.ucdavis.edu/data/reports/wheat-n) and N content of protein is taken as $16.8 \%$ (Source: http://en.wikipedia.org/wiki/Protein_(nutrient)). Milk 
production of cow is calculated assuming 255 days of lactation period for local cow and meat production of goat is adapted from Khan and Usmani (2005) based on local price. Out of the total maize grain production, $730 \mathrm{~kg}$ of it is used as feed for the livestock and thus deducted from the total yield. Protein content in milk is on an average 6.54\% (Mecha et al., 2008). $\mathrm{N}$ deposition is taken from Farm Dances.

The result in table 4 shows that Nitrogen balance of the system is negative and nitrogen use efficiency is more than 100 percent. It is a good indicator in general, that whatever the amount of $\mathrm{N}$ applied into the system, more than that is taken up by the plants and animals out of the system. But, here arises a question that from where the excess amount of $\mathrm{N}$ goes out of the system. It is none other than from the soil. It indicates that the soil $\mathrm{N}$ content is decreasing resulting into the degradation of land. It will need more and more amount of fertilizers to be applied to produce the same amount of produce (may be even more to feed the increasing number of family members) from the system in future. In short term, these indicators seem satisfactory but in the long term it will have definitely negative impact on the soil quality that reduces the crop yield rendering the system unsustainable.

\section{SOCIAL SUSTAINABILITY}

For the family with 5 individuals, grain production seemed to be adequate but the system was not producing other crops like vegetables and fruits. They have to purchase those vegetables, legumes and other requirements from outside the system. They need to invest in education, recreation, health, security, technology and so on. But surplus of only NRs 79,449 per year is not sufficient for making a minimum living. This condition leads to the poor health, poor education, and poor saving of the family indicating the system socially unsustainable rendering the farm family more and more poor.

\section{DISCUSSIONS}

With the increased pressure of ever growing population on the marginalised farm in developing country lead to the farming system vulnerable. The farming system in those areas is basically subsistence and mixed. Farmers produce only for making daily consumption. With the limited use of external inputs and growing demand of farm produces make the system vulnerable. In these regards, the main aim of this paper was to analyse different aspects of sustainability namely social, economic and ecological sustainability. The results indicated that the growing pressure on land has been rendering the system towards economically, ecologically and socially unsustainable. Enterprises like cow rearing, millet farming was negative in gross profit margins. The question is why the farmers are having those enterprises in spite of their negative gross margin. The selection of non-profitable enterprises is due to the lack of any alternatives. They are growing finger millet in the land where other crops are not possible due to the lack of adequate input and irrigation. The animals they are rearing and the varieties of crops they are growing are local ones. Due to the lack of technological know-how and resources, they cannot use improved breeds and varieties. 
The analysis of ecological sustainability depicts even more shocking result of degrading land condition. The increased pressure of producing more crops to feed increasing number of population on land leads the depletion of the soil nutrients content. The degradation rate seems to be in increasing order over time as the nitrogen balance in the soil is negative. Poverty is the root cause in those farming system that leads to unsustainable farming activities rendering the system more and more vulnerable in future.

Figure 1 illustrates how the poverty leads to negative environmental impact and reduced crop yield in a farming system. Lack of off-farm employment leads to the pressure on farm, but due to the limitation of resources the farmer cannot use balanced amount of fertilizers. This results in the nutrient depletion from the soil. This is also conditioned by the accelerated soil erosion due to improper land use and poor management. Finally, nutrient depletion out of the system leads to the reduction in yield and negative environmental impacts like loss of vegetation, landslides, erosion and so on.

$(\longrightarrow$ direct influence and

Cinfluence to a large extent)

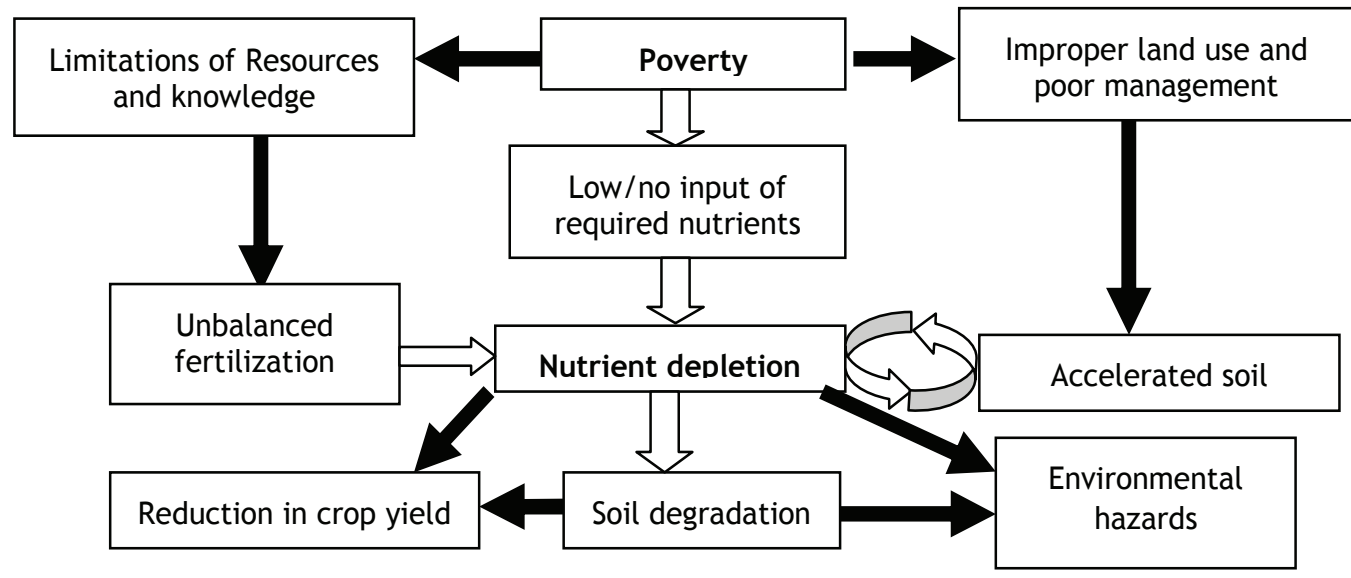

Figure 1. Human Induced Soil Nutrient Depletion and its Impacts (after Tan et al., 2005)

The farm is producing only cereals. This may be due to the lack of road network to sale their produce, lack of knowledge and lack of irrigation facility. They could grow vegetables in winter season to make more profit. For overall sustainability, system redesign for increasing above and below ground diversity, biomass production and soil organic matter increment, efficient use of locally available resources, optimal animal and plant balance, enhancement of functional complementarities of farm components needed, as suggested by Altier (2002). For improving soil health other measures including use of cover crops, green crops to retain $\mathrm{N}$ in the soil, regular soil analysis, introduction of the legume in the system, use of lime to maintain the optimum $\mathrm{pH}$ so as to maximize the available nutrient use, use of recommended dose of fertilizer and apply when it is most needed to minimize the losses, appropriate and scheduled irrigation, use appropriate control 
measures for minimizing pest, diseases and weeds and raising of improved livestock breeds can be the best possible alternatives.

The author has experienced that in those farms, farmers use farm yard manures which are not fully decomposed. They do not cover the manure pit and transport the manure to the field before one month of seeding and leave it without mixing into the soil. It results in the $\mathrm{N}$ volatilization losses. So, they have to train in this regards as well.

Though the study is based on a single hypothetical farm, the findings cannot be generalised. But, the hypothetical farm was taken as an average farm representing all similar farms of the region in the country. In this regard, the results of the study are taken to be representative of the similar area. Only few indicators for the sustainability dimensions namely social, economic and ecological, are taken under consideration to study the issues due to the lacks of time and limited scope of the study. A detailed study taking all the indicators of sustainability into account would be more meaningful to generalise the findings of the study. Still, the study provides a general picture of the sustainability of the farming system in such areas.

\section{CONCLUSIONS}

To conclude, all dimensions of sustainability are at risk in a subsistence Nepalese farming system. The problem is related with poverty. Sufficient investment by the government in infrastructures like roads, electricity, irrigation structures, and credit and for training and education to awareness in such areas is needed. The government has to focus on research on alternative technologies. The farmers might go for cooperative to pool resources, credit provisions and efficient marketing of inputs and output. Appropriate land policy from the part of government is needed to reduce the land fragmentation so as to commercialize the agriculture by applying improved technologies.

\section{REFERENCES}

Agrifood Consulting International, Nepal, 2003. Fertilizer Use Baseline Study, Volume 1. A Report Prepared for His Majesty's Government of Nepal, Ministry of Agriculture and Cooperatives.

Agro Enterprise Centre, Market information Service (MIS), Nepal, Retrieved 7 Dec. 2011 from http: //www.agripricenepal.com.

Altieri, M.A, 2002. Agroecology: the science of natural resource management for poor farmers in marginal environments. Agriculture, Ecosystems and Environment 93:1-24.

Boogaard, B.K., Oosting, S.J. and Bock, B.B., 2008. Defining sustainability as a socio-cultural concept: Citizen panels visiting dairy farms in the Netherlands. Livestock science 117:24-33.

CBS, 2011/12. National Sample Census of Agriculture. Central Bureau of Statistics, Nepal. Retrieved $13 \quad$ May, 2014 from http://cbs.gov.np/wpcontent/uploads/2013/12/Summary-of-Agriculture-Census-2011.pdf.

DOA, 2009/10. Annual progress book (in Nepali language), Retrieved 5 Dec. 2011 from http://www.doanepal.gov.np/publications.php.

Goulding, K., Steve, J. and Andy, W., 2008. Optimizing nutrient management for farm systems. Phil. Trans. R. Soc. B 363:667-680.

Kates R. W., Thomas M. P., Robert W. and Anthony A. L., 2005. What is sustainable development? Goals, indicators, values, and practice 47(3):8-21. 
Khan, R. N. and Usmani, R. H., 2005. Characteristics of rural subsistence small holder livestock production system in mountainous areas of Pakistan. Pakistan Veterinary Journal 25(3).

Mech A., Dhali, A., Prakash, B. and Rajkhowa, C., 2008. Variation in milk yield and milk composition during the entire lactation period in mithun cows (Bosfrontalis). Livestock Research for Rural Development 20(75).

MOAC, 2011. Statistical year book, 2010. Retrieved 6 Dec. 2011 from http://www.moac.gov.np.

MoAD, 2012/13. Statistical Information on Nepalese Agriculture. Ministry of Agricultural Development, Government of Nepal. Retrieved 13 May, 2014 from http: / / www.moad.gov.np/yearbook/ YearBook2013Whole.pdf.

OECD, 2008. Insights Sustainable Development: Linking Economy, Society, Environment. ISBN 978-92-64-055742. $\quad$ Retrieved 13 May, 2014 from http://www.oecd.org/insights/41773991.pdf.

Pilbeam C. J., Tripathi, B. P., Munankarmy, R.C. and Gregory, P.J., 1999. Productivity and economic benefits of integrated nutrient management in three major cropping systems in the mid-hills of Nepal. Mountain Research and Development 19(4):333344.

Tan Z.X., Lal, R. and Wiebe, K. D., 2005. Global Soil Nutrient Depletion and Yield Reduction. Sustainable Agriculture 26(1):123-146.

Other online subscriptions

http://ltras.ucdavis.edu/data/reports/wheat-n (For nitrogen content of wheat), Subscribed on 2011-12-07.

http://www.fao.org/docrep/t0567e/T0567E08.htm (For nitrogen content of rice and maize), Subscribed on 2011-12-07.

http://en.wikipedia.org/wiki/Eleusine_coracana (For protein content of finger millet), Subscribed on 2011-12-07.

http://www.foodsci.uoguelph.ca/dairyedu/chem.html (For milk protein content), Subscribed on 2011-12-07.

http://en.wikipedia.org/wiki/Protein_(nutrient) (For protein $N$ content), Subscribed on 2011-12-07. 